\title{
Linha de Pesquisa: de Remendos a Remates
}

Jairo Eduardo Borges-Andrade

Convidado pela Revista de Administração Contemporânea (RAC) para escrever um ensaio explorando o conceito de linha de pesquisa, finalizei o texto afirmando que sequer poderia acreditar que o assunto, tão controvertido, pudesse ter ficado bem arrematado. Aquele texto principalmente identificou, descreveu, produziu e organizou remendos.

Das réplicas prometidas, eu esperava argumentos que combatessem e contestassem o que eu tinha escrito, pois estava consciente de que faltava acabamento. Tendo recebido as mencionadas réplicas, constatei que os seus autores optaram por uma estratégia de colaboração e contribuição, resultando numa construção coletiva do conceito de linha de pesquisa. Os remates estão muito melhores do que antes.

Do Professor Menandro vieram comentários que deram acabamento à constatação dos problemas históricos do conceito de linha de pesquisa. Um esquema foi apresentado, ajustando sensivelmente a proposta de conceito que eu havia esboçado. Foi feita uma importante reflexão sobre os riscos do mau uso dessa vestimenta.

O Professor Jaime deu amarração à hierarquia que eu havia proposto, fortalecendo a sua visão institucionalista e lembrando que pesquisa e ensino devem ser indissociáveis. Mais que isso, ele avançou no sentido de propor elementos relativos à gestão de linhas de pesquisa, ao utilizar a metáfora de ciclos de vida.

Porém a veste não está acabada. Discutimos um pouco a história e o conceito de linha de pesquisa e até mesmo alguns aspectos da sua possível gestão. Mas eu gostaria que isso fosse completado com casos, no velho e bom estilo da Administração. Seria bastante ilustrativo o relato de experiências de construção e gestão de linhas de pesquisa, talvez tentando interpretá-las com o que elaboramos até aqui. Além disso, os textos publicados como resultado do presente debate, acabaram por priorizar bem mais a questão das linhas de pesquisa nos Programas de Pós-Graduação. Falta tratar melhor a questão das linhas de pesquisa nos Grupos de Pesquisa.

Réplicas não foram feitas. Fiquei na confortável posição de não precisar fazer uma tréplica. Não havia o que refutar ou responder. Assim, graças aos mencionados professores, minha tréplica fica aqui convertida, e não reduzida, a uma conclusão. 